American Journal of Environmental Sciences 5 (4): 494-500, 2009

ISSN 1553-345X

(C) 2009 Science Publications

\title{
Groundwater in the Urban Environment: Management Needs and Planning Strategies
}

\author{
Stefano Lo Russo and Glenda Taddia \\ DITAG-Department of Land, Environment and Geo-Engineering, Politecnico di Torino, \\ C.So Duca Degli Abruzzi 24, 10129 Torino, Italy
}

\begin{abstract}
Problem statement: Over the past thirty years urban transformations, such as urbanization, suburbanization, dis-urbanization and re-urbanization processes, have modified the subsurface conditions of Torino (NW Italy). In order to contribute to the solution of the problems concerning groundwater the conceptual model for the groundwater flow system, the schematization of the aquifers boundaries and the estimation of basic hydrogeological parameters are among the main issues which should be investigated. This study was mainly aimed at illustrating (i) a new interpretation for the Torino urban area hydrogeological setting (ii) highlighting the current groundwater criticisms and (iii) emphasizing the priority actions to implement a good urban groundwater management system. Approach: Starting from the analysis of the existing subsurface data, a comprehensive description of the general geological setting had been performed, three main (hydro) stratigraphical Units had been described and their reciprocal relationships had been detected. On the basis of the available data, the unconfined groundwater natural seepage had been reconstructed, a hydrogeological map and a cross section illustrating the units characteristics had been produced. Results: The analysis highlighted three main groundwater criticisms: A natural unconfined groundwater level uplifting in the quaternary unit 1, a widespread inorganic pollution under abandoned industrial areas and many interference problems with the groundwater in unit 1 caused by the new transport infrastructures. Another important problem was the scarce geographical density of the existing groundwater monitoring network operating in the urban area. Conclusion: Solutions to specific, local problems can give the opportunity to transform some of the above mentioned problems into useful resources for the territorial development. The expansion of the groundwater observation network clearly appeared to be the main action to be implemented by the public authorities. Other successive actions could be the construction of a multipurpose interactive real-time mathematical model of groundwater movement in the urban area and the development of improved methods for predicting changes of hydrogeological conditions.
\end{abstract}

Key words: Groundwater, monitoring, urban planning, Torino, Piemonte

\section{INTRODUCTION}

Urbanization modifies hydrology locally, often extensively. Water and chemical fluxes are changed in both surface and groundwater systems, often to the detriment of the environment and the water usability. Depending on which factors dominate, possible implications of these changes include: Reduced well and river yields; increased flood hazard; deterioration in groundwater quality; salinization; poor quality baseflow; migration of polluted urban groundwater into surrounding rural areas and increased ground instability $^{[10]}$.

Analysis results demonstrate that the elements most affecting the hydrodynamic and hydrochemical characteristics of groundwater beneath urban areas are seepage from underground pipes, infiltration of irrigation water, waste discharge, leakage from artificial reservoirs and tanks and installations which impede groundwater flow, such as building foundations. However, there also may be significant outflows such as groundwater production, underground withdrawal from drainage systems and subway discharge wells which partially offset the groundwater inflows.

Torino city is located in the Piemonte Region in the north-western area of Italy, on the Po river plain, south of the western Alps (Fig. 1). It is Italy's fourth largest city, with a total population of 906,000 inhabitants at the end of 2007 and it covers an area of $130 \mathrm{~km}^{2}$ with a population density of less than 7,000 inh $\mathrm{km}^{2}$.

Corresponding Author: Stefano Lo Russo, DITAG-Department of Land, Environment and Geo-Engineering, Politecnico di Torino, C.So Duca Degli Abruzzi, 2410129 Torino, Italy Tel: +39 0110907648 Fax: +39 0110907699 


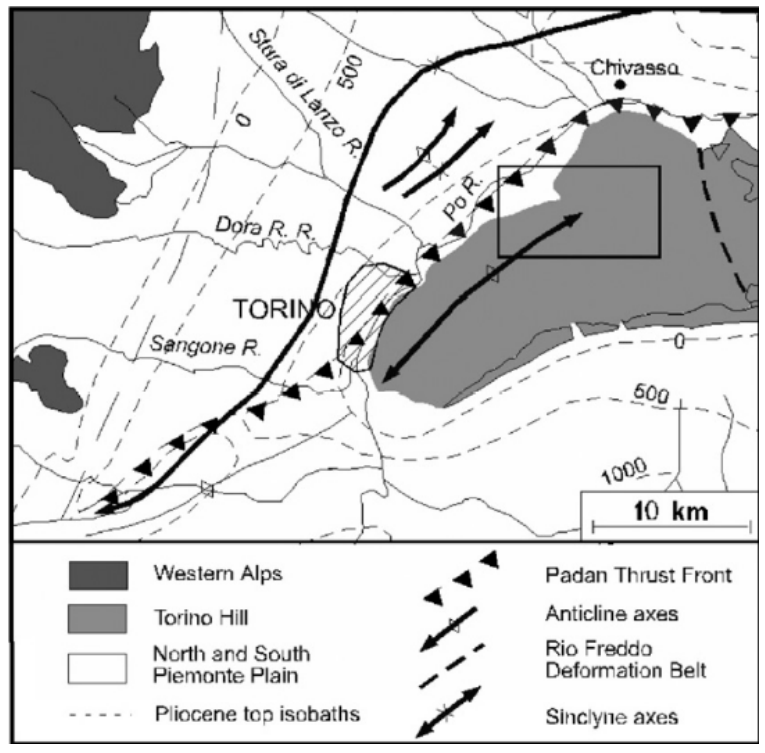

Fig. 1: Structural sketch of the Torino Hill

Its metropolitan area comprises 53 municipalities and has about 1,700,000 inhabitants. Similarly to what happened in other European or North American metropolises, in the last decades the crisis of the large Fordist industry has affected Torino urban area and produced great transformation, involving both its economic and productive apparatus and its urbanistic and social framework. From Torino's 700,000 inhabitants at the end of the 1940's, the population grew to $1,205,000$ individuals in 1974, on the threshold of the crisis involving Fiat, the area's largest industry. It then decreased to its current population of 906,000 inhabitants, the same number registered in 1957, when the city's population grew to more than one million inhabitants and maintained that number for exactly thirty years (1961-1991). The demographic and economic evolution of Torino over the past 30 years reflects the processes of urban development in most industrialized countries: Urbanization, suburbanization, disurbanization and re-urbanization. Despite this deindustrialization process Torino's current economy is still linked to the car and car components industries. Other important industrial sectors in the city include industrial automation, aeronautical parts, information technology and satellite systems. Over the last fifteen years the territorial evolution has produced effects on the intensive urban transformation processes mainly represented by the progressive re-organization of the metropolitan transport network (including the construction of a railway link and the first line of the subway system) and lots of urban regeneration projects, transforming abandoned industrial (polluted) sites in restored new houses and services areas (commercial, cultural and, partly, productive). The dynamic consequences of these intense and rapid transformations affected significantly the environmental conditions of the urban groundwater system. Pollution caused by industrial activities, permanent perturbation in the natural seepage connected to excessive withdrawals, interference between new buildings and natural subsurface system are among the major effects of the anthropogenic patchy actions performed on the Torino urban area over the years.

The analysis and comparison of the current hydrogeology problems in urban areas, urban agglomerates and industrial centers ${ }^{[9,10,12]}$ highlight the need for a hydrologically sustainable city: it is necessary to find a balance for drainage, flooding, waste disposal and water supply. This is unlikely to be established without active management initiatives and the definition of possible detrimental impacts on the groundwater and other environmental matrices. The conceptual model for the groundwater flow system, the schematization of the aquifer boundaries and the estimation of basic hydrogeological parameters are among the main issues which should be investigated to develop a sustainable, scientifically supported urban groundwater management system. These basic elements need to be revised on a regular basis, considering the evolution of the groundwater system and its interference with the variable urban development.

Therefore, this study is mainly aimed at illustrating comprehensively (i) A new interpretation for the Torino urban area hydrogeological setting, (ii) Highlighting the main environmental criticisms connected to current groundwater uses and (iii) Emphasizing the priority actions required to implement a good urban groundwater management system.

\section{MATERIALS AND METHODS}

General geological setting: Torino urban area is mainly developed on the outwash plain constituted by several glaciofluvial coalescing fans connected to the Pleistocene-Holocene expansion phases of the Susa glacier. The plain extends between the external RivoliAvigliana Morainic Amphitheatre (RAMA-Susa Glacier) on the west side and the Torino Hill on the east. The study zone has been limited by the Stura di Lanzo draining river on the north and by the Sangone river on the south respectively (Fig. 2). These streams and the Dora Riparia river in the central portion of the study area dissect the plain and discharge in the main draining Po river that flows towards NE along the western border of Torino Hill. 


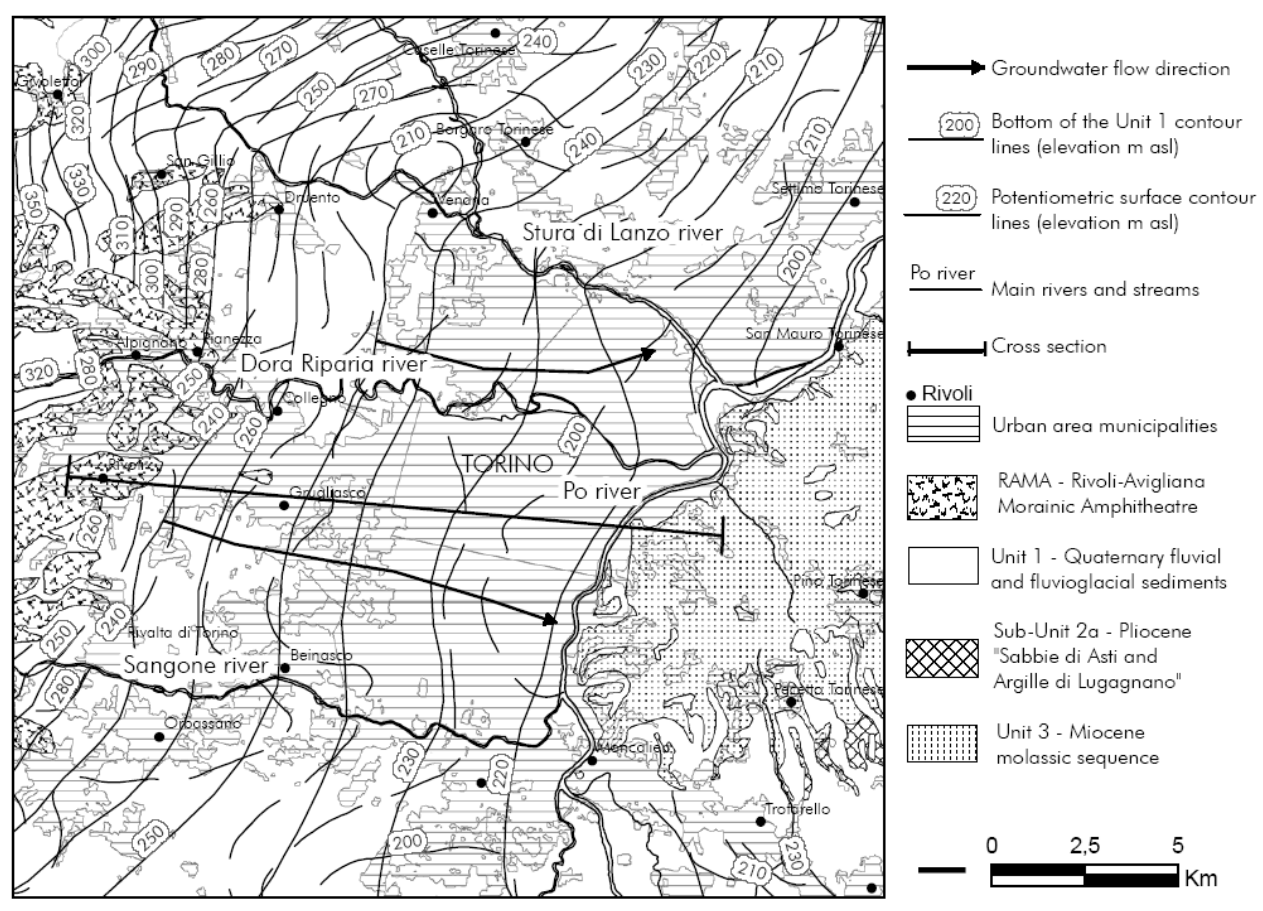

Fig. 2: Hydrogeological map of Torino urban area

The outwash plain substrate outcrops in correspondence of the Torino Hill and is constituted by a Cenozoic terrigenous marine succession deposed in an episutural basin ${ }^{[1]}$. The deposition of this Eocene to Pliocene sedimentary succession is a consequence of syn-orogenetic demolition of the Alpine range during its evolution. Structurally, the Torino Hill corresponds to an asymmetric anticline verging to the NW, with a SW-NE oriented axis. The buried Padan Thrust overthrusts it onto the Po plain fore-deep. The "Rio Freddo Deformation Belt", a left transpressive shear zone, separated the Torino Hill from the Monferrato Relief ${ }^{[3]}$ (Fig. 1).

First hypothesis concerns the aggradation of the plain sector north of the Torino Hill (North Piemonte Plain) by Northern Piemonte Plain watercourses (Dora Riparia, Stura di Lanzo, Orco and Dora Baltea Rivers) and the absence of the Po River north of the relief during most of the Pleistocene ${ }^{[7]}$. Subsequent detailed studies established the palaeo-Po River south of the Torino Hill. Several abandoned entrenched meanders on the southern slope of the relief and on the Poirino Plateau, with silty and lesser gravelly deposits, are connected to this collector. The current setting of the Po River, north of the Torino Hill, is very recent and linked to a fluvial diversion that occurred at the end of the Late Pleistocene $^{[8]}$.
More comprehensive research suggested the different geodynamic evolution of the hilly sector and the plain sector: A marked uplift during the PlioQuaternary in the Torino Hill and a moderate lowering during the Early Pliocene as well as a weak uplift during the Middle-Late Pliocene and Quaternary in the plain sector ${ }^{[2]}$. The different recent evolution of these two areas caused the re-organization of the hydrographic network during the Quaternary. Subsequent research on the morphological and geological evolution of the western and northwestern slopes of the relief revealed the existence of a complex Pleistocene terraced fluvial succession. This evidence is distributed at different elevations and variously perched on the Po Plain. The mineralogical analyses of the related fluvial deposits suggested a genetic link with the Stura di Lanzo and Dora Riparia Basins. More specifically, the trends of the upper terraces indicated that during the first part of the Middle Pleistocene the watercourses whose relics are now involved in the western slope of the relief flowed to the south, whereas those involved in the northwestern slope flowed to the northeast. The trends of the lower terraces indicate that during the upper part of the Middle Pleistocene and during the Late Pleistocene the whole area was part of a single basin drained by a NE-flowing watercourse. 


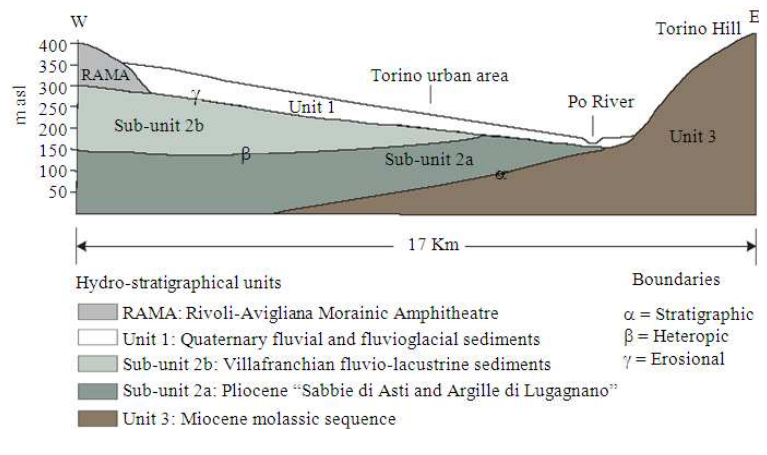

Fig. 3: Cross section and stratigraphic relationships

(Hydro) Stratigraphical relationships: As a result of this complex Pliocene-Holocene evolution, the urban area plain geological setting is characterized by a strong geographical anisotropy. Since the last part of XIX century qualitative and quantitative analysis of subsurface data regarding Torino city area were performed by the Italian "pioneers" of geology and hydrogeology. In the following decades these first sources of geological information were intensively increased by the construction of several new buildings, roads, railways, water wells, though always in a disaggregate way. Recently, comprehensive geological and hydrogeological studies concerning Torino urban area $^{[4-6]}$ collected the available geological data including the "historical" information, trying to produce integrated geo-referred database and maps, which are very useful for the definition of subsurface geo-setting and the interpretation of the groundwater phenomena. A broad analysis of this database has lead to a new interpretation of the subsurface stratigraphical relationships among the different (hydro) geological bodies, which is proposed in this study. Three main (hydro) stratigraphical Units have been distinguished based on depositional age, structural setting, lithological composition and hydrogeological properties (Fig. 3). Their characteristics and relative relationships are described below.

The oldest unit (Unit 3-Miocene) is constituted by conglomerates, sandstones and marls typical of the molassic sequence belonging to the Piemonte Tertiary Basin. The upper part is locally characterized by the presence of evaporites belonging to the Messinian Gessoso-solfifera formation. Unit 3 is stratigraphically overlapped by the subsequent Unit 2 (Pliocene) (surface $\alpha$ ) or truncated by the main erosional quaternary surface $(\gamma)$ and therefore directly in contact with the upper outwash deposits (Unit 1-Quaternary). Despite the limited deep geological evidences the stratigraphic correlations within Unit 3 confirm the presence of the buried extension of the asymmetric anticline verging to the NW, with a SW-NE axis characterizing the Torino Hill sector.

Unit 2 can be subdivided in two different SubUnits characterizing different sedimentation environment with a lateral heteropic transitional relationship (surface $\beta$ ). The Sub-Unit $2 \mathrm{a}$ originally deposited in a shallow marine environment and traditionally defined as Sabbie di Asti and/or Argille di Lugagnano is mainly composed of fossiliferous sandyclayey layers with subordinate fine gravely and coarse sandy marine layers or by quartz-micaceous sands with no fossil evidences. The heteropic Sub-Unit $2 b$ shows fluvio-lacustrine faces and is usually referred to as the Villafranchian. It consists of fine-grained sediments (sand, silt and clay with inter-bedded gravel) divided into several sedimentary bodies. Typical litho-faces are blue-grayish clayey sands and silts and yellowish to grayish sands and silts, usually with a rhythmic or pseudo-varved structure. At a local level it is possible to recognize fan-delta deposits formed by gravel layers in a sandy matrix and, less commonly, boulders in a sandy-silty-clayey matrix. The top of Unit 2 was eroded away (surface $\gamma$ ) and covered by the outwash alluvial deposits characterizing Unit 1. Outcrops of Unit 2 are to be found on the southern side of Torino Hill. On the opposite, Unit 2 is fully buried under Unit 1 in the Torino city and it can be recognized only by analyzing logs data. The structural setting highlights a variable situation: Unit 2 dipping is directed towards ESE in the urbanized western portion (near the RAMA) and on the opposite direction WNW close to the hilly sector on the east side. The overall thickness of Unit 2 is strongly variable but in some deep water wells near Venaria Reale municipality (northern sector) it reaches over $180 \mathrm{~m}$. Below Unit 1, the Sub-Unit 2a tends to be prevalent in the municipalities of Settimo and Leinì in the north and Moncalieri, Candiolo, Vinovo and None in the south, whilst the Sub-Unit $2 b$ is mainly common below the Quaternary cover in the municipalities of Venaria Reale, Borgaro, Druento, Alpignano, Collegno and Rivoli. In the southern urban area the identification of the surface $\gamma$ between Unit 1 and 2 is difficult due to the sandy lithological faces similarity.

The youngest unit (Unit 1-Quaternary) is constituted by fluvial and fluvioglacial coarse gravels with subordinate sands and silts (locally cemented) derived from alluvial fans aggraded by the alpine rivers down-streaming towards east. Unit 1 covers almost the whole plain in the investigated area. The presence of many stream terraces that flank parallel to the stream channels, highlights a past sequence of fluvial erosion or deposition events in the flood plain during the 
Quaternary. The Unit 1 average thickness is $30-40 \mathrm{~m}$ with a general trend decreasing from $\mathrm{W}$ to $\mathrm{E}$ and $\mathrm{NE}$. More precisely it changes from $70 \mathrm{~m}$ in Grugliasco and Collegno municipalities (W) to less than $9 \mathrm{~m}$ near the Po river on the eastern border. However, in the northern portion near Settimo, it reaches $20 \mathrm{~m}$ rarely. In the overall investigated sector Unit 1 appears subhorizontal. Unit 1 bottom (erosional surface $\gamma$ ) gently dips $(0.23 \%)$ towards north-east generally overlaying Unit 2 or directly Unit 3 along the Po river.

Groundwater and aquifers: The hydrogeological regional setting is strongly influenced by the presence of the Rivoli-Avigliana Morainic Amphitheatre (RAMA) on the west side and the Torino Hill sector on the east. The buried lithotypes of Unit 3 below Units 1 and 2 (Fig. 3) represent the bottom impermeable layer for the unconfined groundwater regional down-flowing towards east mainly developed in the quaternary deposits (Unit 1). As a matter of fact, Unit 1 represents an important unconfined high productive aquifer hydraulically connected to the main surface water drainage network (Sangone, Dora Riparia, Stura di Lanzo and Po river). The permeability can reach high values $\left(\mathrm{K} 1=1 \times 10^{-3} \div 1 \times 10^{-4} \mathrm{~m} \mathrm{sec}^{-1}\right.$ ) depending on the local sediment granulometry. This aquifer is quite vulnerable to pollution because of its shallowness and the absence of significant natural barriers (clay levels) in the sedimentary body. The potentiometric surface shows generally a $\mathrm{W}$-to-E gradient ranging from 0.6$1.2 \%$ (mean $0.9 \%)^{[6]}$. The analysis of the groundwater flow pattern highlights different relationships between the unconfined aquifer and the surface water network depending upon the local hydrogeological characteristics. Generally the rivers Sangone, Dora Riparia and the last part of the Stura di Lanzo river show a draining behavior, whilst the upper part of the Stura di Lanzo tends to recharge the aquifer. Along Torino Hill the Po river drains both the surface than the groundwater hosted in Unit 1 . The depth to groundwater is highly variable from $60 \mathrm{~m}$ in the high morainic plain (west side, near the RAMA) to few meters in the surrounding area of the Po river.

Unit 2 hosts an highly productive multi-aquifer system intensively pumped for human consumption. This aquifer shows only a moderate intrinsic vulnerability to pollution, due both to its depth (on average, the top of Unit 2 is at $30-40 \mathrm{~m}$ depth) than to many clayey inter-layers subdividing the formation. The Unit 2 aquifer recharge mainly occurs in a transitional zone across the upper erosional surface $(\gamma)$ by downward flow from Unit 1 unconfined aquifer. The inter-bedded clayey impermeable levels can confine the water bodies hosted in the aquifer and the related potentiometric effect grows with Unit 2 thickness.

Due to the lithological composition and the tectonic setting, Unit 3 hosts confined aquifers scarcely productive. In the hilly sector they are exploited mainly for domestic uses. The recharge of the Unit 3 aquifer follows a mechanism similar to the Unit 2 aquifer in those portions where Unit 1 overlays directly Unit 3 (along the Po river).

\section{RESULTS AND DISCUSSION}

Groundwater problems and required planning actions: The integration between the historical information on water quality and quantity and the large amount of subsoil information collated in the last twenty years due to the construction of important buildings and infrastructures (i.e., the SPINA industrial areas regeneration processes, the new subway and railways lines, the XX Olympic Winter Games plants) allows some considerations about the current condition of the groundwater environmental state in Torino urban area. The analysis highlights three main existing criticisms:

- In some portions of the urban area the reduced withdrawals connected to the abandon of industrial water wells screened in Unit 1 produce a natural unconfined groundwater level uplifting. Groundwater interests building foundations and subsurface parking areas producing structural damages to the infrastructures, so that major drainage works are needed

- Inorganic pollution under abandoned industrial areas are quite widespread. In most cases, this concerns Unit 1 unconfined aquifer only but, in some cases, significant levels of pollutants have been detected in deep aquifers hosted in Unit 2. Some effects of this pollution can be observed in the Torino hinterland as well

- The development of transport infrastructures such as the new subway in the subsurface space produce interference problems with the natural groundwater seepage in those areas with limited depth to groundwater. The occasional barrier effect influences existing buildings and damages the underground constructions (i.e., tunnels, parking areas)

These main criticisms make it necessary to find solutions to specific, local problems in a context of a general groundwater managing philosophy. Recently, public authorities and stakeholders (construction 
enterprises, professionals, universities) have tried to solve specific groundwater problems linked to quantitative and qualitative aspects. Many experiences have been tested locally, leading to good results. Restrictions to specific discharges and withdrawals as well as the improvement of sewerage and depuration infrastructures, detailed land use provisions, meticulous subsurface investigation, numerical modeling and many other problem-solving skills have been developed and they represent important know-how for implementing a complete, effective groundwater management system. Therefore, it stands out that various safeguard measures and technical solutions to specific groundwater problems may have the potential for transforming some of the difficulties mentioned into useful resources for the territorial development. For example, the general necessity to reduce $\mathrm{CO}_{2}$ emissions incentives the wide diffusion of the open-loop Groundwater Heat Pumps system (GWHP) to provide cooling and heating, especially for new buildings. The withdrawals connected to this (relative) new technology can represent a solution in those restoration processes in which the natural groundwater uplifting can limit the subsurface uses. Moreover, the local removing of pollution sources (buried tanks, waste disposal) in the sites restoration actions not only provides adequate conditions for human households settlement in the specific re-urbanization process, but it can also improve the general groundwater environmental state

As a matter of fact, each modern solution to the specific local groundwater problem suggests that an adequate groundwater monitoring network is an important pre-requisite. In particular, difficulties linked to the interferences between the subsurface buildings and the natural groundwater seepage can be solved only through detailed early hydrogeological investigations and numerical modeling provisions that cannot avoid considering opportune groundwater data, deriving by monitoring. The analysis of the current groundwater monitoring network consistency in Torino urban area reveals an inadequate situation. The regional authority directly manages a groundwater monitoring network as defined by the Water Protection Plan (WPP) ${ }^{[11]}$. In compliance with the national law 152/06, the regional environment protection agency (ARPA) measures water temperature, electrical conductivity and water level on each monitoring point, at least twice a year. Water samples are collected and analyzed in laboratories in order to control the main chemical parameters and identify any pollutants. Data are used to verify trends in hazardous substances (nitrates, phosphorous, DNAPL) and to define planning actions and restrictions in land management, if necessary. After validation, data are published, also by means of the regional authority Web site (www.regione.piemonte.it). At the end of 2007 the regional network consisted of 446 points for water table and 211 points for deep aquifers. Consequently, the consistency $\left(0.44\right.$ points $\left./ 10 \mathrm{~km}^{2}\right)$ on a regional scale is still far from the optimal target of 1 monitoring point/10 $\mathrm{km}^{2}$ set out by the approved WPP. Moreover the regional distribution is strongly patchy. Among the less monitored zones, Torino urban area plain shows the worst situation ( 0.14 points $\left./ 10 \mathrm{~km}^{2}\right)$ being equipped with 12 points only checking groundwater in Unit 1 . No monitoring stations provide information about Unit 2 aquifer. As a consequence, a major, comprehensive action focused on implementing a suitable groundwater monitoring network is top priority, in order to establish an integrated management system really useful for quantitative and qualitative groundwater problemsolving.

\section{CONCLUSION}

In urbanized areas there are many types of influence on groundwater systems. The specific features of urban loadings (natural and anthropogenic) can be described by the following characteristics: multifactor; varying effects on either or both recharge and discharge; irregularity in time and space; concentration within a limited area. The character, rates and degree of change in hydrogeological conditions are as directly dependent on the joint action of the loads imposed by anthropogenic influences as they are on the specific characteristics of geological, hydrogeological and hydrological conditions. Irrespective of features of the natural system, the presence of anthropogenic influences on groundwater results in the development of harmful effects within the majority of urban areas, including Torino. For developing and performing scientifically justified management and sustainable development of urban water systems, it is necessary to obtain complete and accurate information and data concerning the on-going phenomena which involve groundwater and the urban transformation development.

The hydrogeological setting of Torino urban area and the evaluation of the current criticisms for its groundwater system highlight the necessity to implement any actions that may improve the knowledge of the transient subsurface phenomena acting at the present time. In fact, an excessive lack of information could lead to dangerous planning errors and worsen local situations.

The expansion of the groundwater observation network in urban areas would provide complete 
information on natural and anthropogenic impacts on groundwater at both regional and local level and clearly appears to be the main action that public authorities (regional and/or municipality) should put into practice as soon as possible. At a later stage, some other priority actions could be carried out, such as the construction of a multi-purpose interactive real-time mathematical model of groundwater movement in the urban area to predict changes in hydrogeological conditions and limit anthropogenic impacts on the environment and the development of improved methods for predicting changes of hydrogeological conditions.

\section{REFERENCES}

1. Bally, A.W. and S. Snelson, 1980. Realms and Subsidence. Facts and Principles of World Petroleum Occurrence, Miall, A.A. (Ed.). Canadian Society of Petroleum Geologists Memoir 6, Calgary, ISBN: 13: 9780920230077, pp: 9-94.

2. Barbero, D., P. Boano, M.T. Colla and M.G. Forno, 2007. Pleistocene terraced fluvial succession, northern slope of Torino Hill. Q. Int., 171-172: 64-71. DOI: 10.1016/j.quaint.2006.12.009

3. Boano, P., M.G. Forno and S. Lucchesi, 2004. Pleistocene deformation of the Collina di Torino inferred from the modeling of their fluvial succession. Italian J. Q. Sci., 17: 145-150. http://www.aiqua.it/abstract/abstract/Volume\%201 7-2A/17_2_1Boano\%20abs.pdf

4. Bottino, G. and M. Civita, 1986. A computer semiquantitative model for microzonation of hazard from interconnection of engineering geological features and urban sub-service network. Proceeding of the 5th International Congress on IAEG, Oct. 20-25, Buenos Aires, Argentina, pp: 1731-1740.

http://books.google.com.pk/books?id=ctAkAjMM_ d0C

5. Bottino, G. and M. Civita, 1986. Engineering Geological Features and Mapping of Subsurface in the Metropolitan Area of Turin (North Italy). In: Groundwater in the Urban Environment, Chilton, P.J. et al., (Eds.). Taylor and Francis, Bakema/Rotterdam, ISBN: 9061916631, pp: 662.
6. Civita, M., S. Lo Russo and B. Vigna, 2004. Hydrogeological sketch map of Piemonte (NW Italy) 1:250.000. Proceeding of the 32nd International Geological Congress, Aug. 21-28, Florence, Italy. http://www.32igc.info/igc32/search/

7. Delle Ricerche, C.N., 1990. Structural Model of Italy, scale 1:500,000, Sheet 1. Progetto Finalizzato Geodinamica, SELCA, Firenze, Italy.

8. Forno, M.G. and S. Lucchesi, 2005. Pleistocene terraced fluvial succession, western and northern slope of Torino Hill Il. Quaternario, 18: 123-134. (In Italian).

http://www.aiqua.it/abstract/abstract/Volume\%201 8-2/18_2Forno\%20abs.pdf

9. Hiscock, K.M., M.O. Rivett and R.M. Davison, 2002. Sustainable Groundwater Development. Geological Society of London Special Publication No. 193, ISBN: 1862390975, pp: 352.

10. Howard, K.W.F. and R.G. Israfilov, 2002. Current Problems of Hydrogeology in Urban Areas, Urban Agglomerates and Industrial Centres. NATO Science Series IV: Earth and Environmental Sciences, Vol. 8, Kluwer Academic Publishers, Dordrecht, ISBN: 1402006004, pp: 500.

11. Regione Piemonte, 2007. Water Protection Plan. DCR n. 117-10731, Turin, Italy. http://www.regione.piemonte.it/acqua/pianoditutela /pianoditutela.htm

12. Tellam, J.H. et al., 2006. Urban Groundwater Management and Sustainability. NATO Series IV: Earth and Environmental Sciences-Vol. 74. Springer, The Netherlands, ISBN: 1402051743, pp: 493. 